\title{
Regulation of somatic embryo development in Norway spruce (Picea abies)
}

\author{
U Egertsdotter * \\ Department of Forest Genetics, Swedish University of Agricultural Sciences, Box 7027, S-750 07 Uppsala, Sweden
}

(Received 30 July 1996; accepted 23 September 1996)

\begin{abstract}
Summary - Somatic embryos can be used for vegetative propagation of genetically superior material. Additionally, the system offers unique opportunities to study embryology. Somatic embryogenesis has been induced in many coniferous species and the process is similar between species. A common problem is, however, that not all embryogenic cell lines contain embryos that can mature. We are using Norway spruce (Picea abies) as a model system to study how the development of the conifer somatic embryo is regulated. Different cell lines contain embryos that have reached a specific developmental stage, which is reflected in the pattern of extracellular proteins and arabinogalactan proteins present. The embryo morphology is partially regulated by proteins. Proteins identified as having a putative regulatory effect on embryo development include chitinases, peroxidases, zeamatin-like proteins and arabinogalactan proteins.
\end{abstract}

Norway spruce (Picea abies) / somatic embryos / embryo development / extracellular proteins

Résumé - Régulation du développement des embryons somatiques chez l'épicéa. Les embryons somatiques peuvent être utilisés pour la propagation végétative de matériels améliorés génétiquement. Cette méthode offre en plus des opportunités uniques pour étudier l'embryologie. L'embryogenèse somatique a été induite chez de nombreuses espèces de conifères selon un processus identique parmi ces espèces. Cependant il faut noter que, de façon générale, toutes les lignées cellulaires embryogènes ne donnent pas forcément des embryons capables de maturation. Nous utilisons l'épicéa (Picea abies) en tant que système modèle pour étudier comment est régulé le développement des embryons somatiques de conifères. Les différentes lignées cellulaires contiennent des embryons qui ont atteint un stade spécifique de leur développement, ce dernier étant caractérisé par un profil de protéines extracellulaires et la présence de protéines arabinogalactiques. La morphologie des embryons est en partie régulée par des protéines ; parmi celles qui ont été identifiées comme ayant un pouvoir régulateur, il y a des chitinases, des péroxydases, des protéines de type zéamatine et des protéines arabinogalactiques.

développement des embryons / embryons somatiques / Picea abies = épicéa / protéines extracellulaires

* Present address: Department of Biology, The Plant Lab, PO Box 373, York Y01 5YW, UK 


\section{INTRODUCTION}

Breeding of forest trees is a slow process in which valuable traits are successively improved. The improvement is obtained by recurrent testing, selection and crossing. Vegetative propagation of trees creates significant advantages for the mass propagation of selected genotypes and as part of the breeding programme. Today the most common way to propagate trees vegetatively is via cuttings. However, the cost of cuttings is high and the rooting ability declines with increasing age of the mother plant. To some extent the problems can be overcome by tissue culture techniques. Somatic embryogenesis is a potentially efficient method for micropropagation and it is in many respects preferable to the methods based on bud differentiation. The advantages with somatic embryogenesis are that the somatic embryos can be propagated on a large scale in bioreactors, a high yield of plants can be obtained in a short time, the embryos are regenerated from mature trees, and the somatic embryos can be cryopreserved (von Arnold et al, 1995).

Development of the somatic embryos are similar between different coniferous species (Jain et al, 1995). Plant regeneration via somatic embryogenesis can be divided into four steps: i) initiation of somatic embryos from the primary explant, ii) proliferation of embryogenic cultures, iii) maturation of somatic embryos and iv) regeneration of plants from somatic embryos (von Arnold et al, 1995). The morphology of the proliferating somatic embryos appear to be crucial for their subsequent capacity to form mature embryos (Egertsdotter, 1996).

We have divided our proliferating embryogenic cell lines of Norway spruce into two groups, A and $B$, based on the embryo morphology and the capacity to mature. Embryos in group A cell lines are well developed and can form mature embryos, whereas embryos in group $B$ are less developed and generally cannot form mature embryos. The group B embryos therefore appear to be blocked in their development. There are also differences between group $A$ and $B$ cell lines in growth, and in the composition of cells and embryos in culture. Furthermore, the secretion of proteins to the culture medium is characteristic for groups (Egertsdotter et al, 1993).

In the medium of embryogenic suspension cultures, substances accumulate that can stimulate the formation of somatic embryos (Hari, 1980). In recent years, much attention has been on the involvement of extracellular proteins during somatic embryo development (for a review, see Schmidt et al, 1994). However, most studies have been in carrot embryogenic cultures although there are apparent similarities between the carrot and the spruce somatic embryos (Egertsdotter, 1996).

Proteins are also secreted in embryogenic cultures of Norway spruce. Some proteins that have been correlated to specific stages in the development of somatic embryos include arabinogalactan proteins, zeamatin-like proteins, peroxidases and chitinases (Mo et al, 1996).

Bioassays show that secreted proteins from group A can stimulate the morphology of group B embryos. More detailed studies of different secreted proteins show that arabinogalactan proteins can influence embryo development, and that different isoforms of chitinases can have either a positive or a negative effect on embryo development (Egertsdotter, 1996).

When trying to reveal the factors determining embryo morphology, we have found that different proteins and a nod factor can stimulate embryo development. However, so far only extracts of mature spruce seeds can release group $B$ embryos from the developmental block. Different experiments show that proteins in the seed extract are responsible for the stimulatory effect. Specifically, chitinase-like proteins, found to be both secreted by group $A$ cell lines and present in seed extract, are of interest (Egertsdotter and von Arnold, unpublished results).

\section{SOMATIC EMBRYOGENESIS IN NORWAY SPRUCE}

Embryogenic tissue is initiated from the primary explant when cultured on medium containing both auxin (2,4-dichlorophenoxyacetic acid; 2,4$\mathrm{D})$ and cytokinin ( $\mathrm{N}^{6}$-benzyladenine; $\left.\mathrm{BA}\right)$. The first-formed somatic embryos continue to proliferate on a medium of the same composition as for initiation. After repeated subculturing onto media of the same composition, an embryogenic cell line is established. The morphology of the somatic embryos within one cell line is similar, but differs between cell lines. The embryo morphology remains stable during prolonged culture and after cryopreservation (Nörgaard et al, 1993). The proliferating somatic embryo can be stimulated to go through a maturation process in which the embryos stop proliferating, increase in size and start to accumulate storage material, including 
starch, proteins and lipids (Feirer et al, 1989; Hakman, 1993). The somatic embryos are stimulated to mature by treatment with abscisic acid (ABA) (von Arnold and Hakman, 1988). Regeneration of plants from somatic embryos is routine in most laboratories working with Norway spruce, although maturation and regeneration are usually restricted to a limited number of cell lines. A major problem in regenerating plants from mature embryos is that the cotyledons and the hypocotyl develop first and thereafter it can be difficult to obtain root development.

\section{CHARACTERIZATION OF EMBRYOGENIC CULTURES}

The proliferating embryogenic cultures contain somatic embryos with different capacities for maturation and regeneration (Jalonen and von Arnold, 1991). The embryos in a specific cell line all reach the same developmental stage. Different cell lines contain embryos that have reached different developmental stages. Accordingly, the cell lines have been divided into two groups, A and B (Jalonen and von Arnold, 1991; Egertsdotter and von Arnold, 1993, 1995; Egertsdotter et al, 1993). Cell lines belonging to group A contain well developed embryos having a large embryonic region, larger than $400 \mu \mathrm{m}$, consisting of more than 2000 small, densely packed meristematic cells; this embryonic region is clearly separated from the suspensor region. The somatic embryos are stimulated to mature when treated with $A B A$. Cell lines belonging to group $B$ contain less developed embryos with an embryonic region smaller than $200 \mu \mathrm{m}$ and composed of less than 300 cells. The embryonic region is not clearly separated from the suspensor region. Group B embryos do not normally respond to $A B A$ by forming mature embryos.

Sieving suspension cultures of group $A$ and $B$ reveal differences in composition. Group A cell lines contain mostly embryos larger than $600 \mu \mathrm{m}$, whereas group B cell lines contain embryos smaller than $600 \mu \mathrm{m}$, a large proportion of single cells and very small aggregates of cells that are smaller than $200 \mu \mathrm{m}$. New embryos with improved embryo morphology can develop from this fraction if isolated from the larger fraction. A similar embryo-forming 'single cell' fraction of the embryogenic suspension culture has been described in carrot (Nomura and Komamine, 1985; Komamine et al, 1992; Toonen et al, 1994).

\section{EXPERIMENTAL SYSTEM}

The group B embryos are apparently blocked in development. By studying the development of these embryos in comparison with group $A$ embryos, we can learn more about regulation of embryo development. More specifically, by studying the effects from different substances on the formation of embryos from the single cells and small aggregates of cells, the effect of extracellular proteins on embryo development could more easily be elucidated.

In carrot, two experimental systems have been used to study the importance of extracellular proteins during somatic embryogenesis. The first system depends on the normal embryo development being interrupted by addition of the fungal antibiotic tunicamycin that prevents $\mathrm{N}$-glycosylation of proteins. The second system is based on a temperature-sensitive mutant (ts11) arrested at the globular stage (Giuliano et al, 1984). By evaluating how different compounds influence the developmentally blocked embryos, regulation of embryo development can be studied.

\section{EXTRACELLULAR PROTEINS}

Somatic embryos of Norway spruce secrete substances into the growth medium that can stimulate embryo development. This was originally discovered i) in solid grown embryogenic cultures that were stimulated to grow faster when cultured on preconditioned solid medium and ii) by the addition of preconditioned medium to newly isolated protoplasts that increased the division frequency. Later studies, running bioassays with concentrated proteins isolated from preconditioned medium, showed that the stimulating effect could be attributed to proteins (Egertsdotter et al, 1993).

Different sets of proteins are secreted by $A$ and $B$ embryos as revealed by in vivo labelling techniques. All together 20 proteins are present in the media from $A$ or $B$ cultures. Three proteins are specifically secreted in group $A$ and one protein specifically in group B (Egertsdotter et al, 1993).

The presence of specific extracellular proteins was correlated with the developmental state of carrot cultures (Satoh and Fujii, 1988) and with the embryogenic potential of cultures of barley (Nielsen and Hansen, 1992) and grapevine (Coutos-Thevenot et al, 1992). In carrot, major 
changes in the extracellular protein pattern occurred upon initiation of somatic embryogenesis (De Vries et al, 1988). In Caribbean pine, the embryogenic state of cell cultures was characterized by specific profiles of extracellular proteins (Domon et al, 1994).

\section{Zeamatin-like proteins}

Of the group A specific proteins, one $28 \mathrm{kDa}$ protein shows around $55 \%$ identity to a class of antifungal proteins which up to now have been found only in monocotyledonous species (Vigers et al, 1991). However, by immunological studies using an antibody towards zeamatin, a few more proteins could be recognized, both in group $A$ and group B (Mo et al, 1996).

\section{Chitinases}

Further immunological identification of specifically secreted proteins showed that certain chitinase-like proteins are secreted in A but not in B (Mo et al, 1996; Egertsdotter and von Arnold, unpublished results). Two different isoforms of chitinase IV have been shown in bioassays to have opposite effects on the embryo development (Egertsdotter and von Arnold, unpublished results). Chitinase 3 , isolated from sugar beet, stimulates the formation of somatic embryos. Another chitinase, secreted from embryogenic cultures of Norway spruce, has a detrimental effect on the embryogenic cells (Egertsdotter, unpublished). Chitinase expression is generally induced by pathogen attack, wounding, ethylene and other abiotic stress factors (Boller, 1987, 1988). However, it has also been shown that chitinase expression is under developmental and hormonal control (Shinshi et al, 1987; Lotan et al, 1989; Samac and Shah, 1991). In carrot suspension cultures, a secreted endochitinase was shown to have a rescuing effect on the mutant ts11 embryos (De Jong et al, 1992). The same effect was mimicked by a bacterial nod factor (De Jong et al, 1993). In spruce, the nod factor NGR234 stimulated the formation of embryos from the 'single cell' fraction (Egertsdotter, 1996).

\section{Peroxidases}

The activity of peroxidases is significantly higher in group A cultures. However, increasing the level of activity in group B cultures did not influence the B embryos (Mo et al, 1996). In carrot, embryos treated with tunicamycin could be rescued by a cationic peroxidase isozyme present in the conditioned medium of control cultures (Cordewener et al, 1991).

\section{Arabinogalactan proteins}

Arabinogalactan proteins (AGPS) are frequently present in the medium of suspension cultured cells and embryos. In Norway spruce, group A and $B$ cell lines contain different amounts and species of AGPs (Egertsdotter and von Arnold, 1995). Isolated AGPs from group A conditioned media, or from extracts of mature seeds, can influence the group $B$ embryos such that the size of the embryonic region increases. In carrot, the pattern of secreted AGPs, as evidenced by crossed electrophoresis, is closely related to the embryogenic potential of the culture (Kreuger and van Holst, 1993). Furthermore, immunological studies showed that specific cells in the suspension cultures carried specific epitopes likely to mark the developmental stage of that cell type (Pennell, 1992). Specific AGP species isolated by antibodies was shown to stimulate embryo formation, whereas other AGP species did not have a stimulatory effect (Kreuger and van Holst, 1995).

\section{SEED EXTRACT}

Total extracts of mature seeds of Norway spruce have a strong effect on the embryogenic cultures of both groups A and B. Growth rate and embryo morphology are stimulated in both groups. The most spectacular effect is, however, on the group $B$ embryos, which will form large and polarized embryos similar to the well developed group $A$ embryos. The seed extract treated B-embryos are also capable of responding to ABA by forming mature somatic embryos.

Seed extracts are known to stimulate somatic embryo formation in carrot (Kreuger and van Holst, 1993). In loblolly pine, the induction of somatic embryogenesis was improved by co-cultivation with the megagametophyte (Becwar et al, 1990) and it was suggested that plant growth regulators are responsible for the stimulatory effect. However, in Norway spruce seed extracts, the active components are likely to be proteins. 


\section{CONCLUSION AND FUTURE DIRECTION}

Evidence is accumulating which suggests that using somatic embryos for clonal propagation is a viable option. Today the technique is readily available for propagation of juvenile material. However, it needs to be extended to a larger number of genotypes. Therefore, it is of special importance to acquire more knowledge on the regulation of somatic embryo development facilitating the use of all types of cell lines for plant production. Our studies have shown that the morphology and development of somatic embryos are, at least partially, regulated by proteins. Somatic embryos secrete proteins that are similar to proteins detected in the extract of seeds. These proteins appear to be important in the regulation of embryo development. Future studies will be directed towards identifying and characterizing the active proteins and determining the mechanisms by which they operate.

\section{REFERENCES}

Becwar MR, Nagmani R, Wann SR (1990) Initiation of embryogenic cultures and somatic embryo development in loblolly pine (Pinus taeda). Can J For Res $20,810-817$

Boller T (1987) Hydrolytic enzymes in plant disease resistance. In: Plant-Microbe Interactions, Molecular and Genetic Perspectives, Vol 3 (T Koshuge, EW Nester, eds), Macmillan, New York, NY, USA, 385-411

Boller T (1988) Ethylene and the regulation of antifungal hydrolases in plants. In: Surveys of Plant Molecular and Cell Biology, Vol 5 (BJ Miflin, ed), Oxford University Press, Oxford, UK, 145-174

Cordewener J, Booij H, Der Zandt H, Van Engelen F, Van Kammen A, De Vries S (1991) Tunicamycininhibited carrot somatic embryogenesis can be restored by secreted cationic peroxidase isoenzymes. Planta 184, 478-486

Coutos-Thevenot $P$, Moes $O$, Jouenne T, Mauro MC, Boulay M, Delarie A, Guern J (1992) Extracellular protein pattern of grapevine cell suspensions in embryogenic and non-embryogenic situations. Plant Sci 86, 137-145

De Jong AJ, Cordewener J, LoSchiavo F, Terzi M, Vandekerckhove J, Van Kammen A, De Vries SC (1992) A carrot somatic embryo mutant is rescued by chitinase. Plant Cel/ 4, 425-433

De Jong AJ, Heidstra R, Spaink HP, Hartog MV, Meijer EA, Hendriks T, LoSchiavo F, Terzi M, Bisseling T, Van Kammen A, De Vries SC (1993) Rhizobium lipo-oligosaccharides rescue a carrot somatic embryo variant. Plant Cell 5, 615-620
De Vries SC, Booij H, Meyerink P, Huisman G, Wilde HD, Thomas TL, Van Kammen A (1988) Acquisition of embryogenic potential in carrot cell-suspension cultures. Planta 176, 196-204

Domon JM, Meyer Y, Faye L, David A, David H (1994) Extracellular (glyco)proteins in embryogenic and non-embryogenic cell lines of Caribbean pine. Comparison between phenotypes of stage one somatic embryos. Plant Physiol Biochem 32, 137147

Egertsdotter E (1996) Regulation of somatic embryo development in Norway spruce (Picea abies). Doctoral thesis, Swedish University of Agricultural Science, ISBN 91-576-5124-8

Egertsdotter U, von Arnold S (1993) Classification of embryogenic cell lines of Picea abies as regards protoplast isolation and culture. J Plant Physiol 141, 222-229

Egertsdotter U, von Arnold S (1995) Importance of arabinogalactan proteins for the development of somatic embryos of Norway spruce (Picea abies). Physiol Plant 93, 334-345

Egertsdotter U, Mo LH, von Arnold S (1993) Extracellular proteins in embryogenic suspension cultures of Norway spruce (Picea abies). Physiol Plant 88, 315-321

Feirer RP, Conkey JH, Verhagen SA (1989) Triglycerides in embryogenic conifer calli: a comparison with zygotic embryos. Plant Cell Rep 8, 207209

Giuliano G, Lo Schiavo F, Terzi M (1984) Isolation and developmental characterization of temperature-sensitive carrot cell variants. Theor Appl Genet 67, 179183

Hakman I (1993) Embryology in Norway spruce (Picea abies). An analysis of the composition of seed storage proteins and deposition of storage reserves during seed development and somatic embryogenesis. Physiol Plant 87, 148-159

Hari V (1980) Effect of cell density changes and conditioned media on carrot cell embryogenesis. $Z$ Pflanzenphysio/ 96, 227 -231

Jain SM, Gupta PK, Newton RJ (1995) Somatic Embryogenesis in Woody Plants, Vol 3, Gymnosperms. Kluwer Academic Publishers, Dordrecht, the Netherlands, 1-388

Jalonen $P$, von Arnold S (1991) Characterization of embryogenic cell lines of Picea abies in relation to their competence for maturation. Plant Cell Rep 10, 384-387

Komamine A, Kawahara R, Matsumoto $M$, Sunabori $T$, Toya T, Fujimura A, Tsukahara M, Smith J, Iro $M$, Fukuda H, Nomura K, Fujimura T (1992) Mechanisms of somatic embryogenesis in cell cultures: physiology, biochemistry, and molecular biology. In Vitro Cell Dev Biol 28P, 11-14

Kreuger M, van Holst GJ (1993) Arabinoglactan proteins are essential in somatic embryogenesis of Daucus carota (L). Planta 189, 243-248 
Kreuger M, van Holst GJ (1995) Arabinogalactan-protein epitopes in somatic embryogenesis of Daucus carota (L). Planta 197, 135-141

Lotan T, Ori N, Fluhr R (1989) Pathogenesis-related proteins are developmentally regulated in tobacco flowers. Plant Cell 1, 881-887

Mo LH, Egertsdotter U, von Arnold S (1996) Secretion of specific extracellular proteins by somatic embryos of Picea abies is dependent on embryo morphology. Ann Bot 77, 143-152

Nielsen KA, Hansen IB (1992) Appearance of extracellular proteins associated with somatic embryogenesis in suspension cultures of barley (Hordeum vulgare L). J Plant Physiol 139, 489-497

Nomura K, Komamine A (1985) Identification and isolation of single cells that produce somatic embryos at a high frequency in a carrot suspension culture. Plant Physiol 79, 988-991

Nörgaard JV, Duran V, Johnsen Ö, Krogstrup P, Baldursson S, von Arnold S (1993) Variations in cryotolerance of embryogenic Picea abies cell lines and the associations to genetic, morphological and physiological factors. Can J For Res 23, 2560-2567

Pennell RI (1992) Cell surface arabinogalactan proteins, arabinogalactans and plant development. In: Society for Experimental Biology Seminar Series 48: Perspectives in Plant Cell Recognition (JA Callow, JR Green, eds), Cambridge University Press, Cambridge, UK, 105-121

Samac DA, Shah DM (1991) Developmental and pathogen-induced activation of the Arabidopsis acidic chitinase promotor. Plant Cell 3, 1063-1072
Satoh S, Fujii T (1988) Purification of GP57, an auxinregulated extracellular glycoprotein of carrots and its immunocytochemical localization in dermal tissue. Planta 175, 364-373

Schmidt EDL, De Jong AJ, De Vries SC (1994) Signal molecules involved in plant embryogenesis. Plant $\mathrm{Mol} \mathrm{Biol} 26,1305-1313$

Shinshi H, Mohnen D, Meins F (1987) Regulation of plant pathogenesis-related enzyme: inhibition of chitinase and chitinase mRNA accumulation in cultured tobacco tissues by auxin and cytokinin. Proc Natl Acad Sci USA 84, 89-93

Toonen MAJ, Hendriks T, Schmidt EDL, Verhoeven HA, Van Kammen A, De Vries SC (1994) Description of somatic embryo-forming single cells in carrot suspension cultures employing video cell tracking. Planta 194, 565-572

Vigers AJ, Roberts WK, Selitrennikoff CP (1991) A new family of plant antifungal proteins. Mol PlantMicrobe Interact 4, 315-323

von Arnold S, Hakman I (1988) Plantlet regeneration in vitro via adventitious buds and somatic embryos in Norway spruce (Picea abies). In: Genetic Manipulation of Woody Plants (JW Hanover, DE Keathley, eds), Plenum Publishing Corporation, New York, NY, USA, 199-215

von Arnold S, Clapham D, Egertsdotter U, Ekberg I, Mo $H$, Yibrah H (1995) Somatic embryogenesis in Norway spruce (Picea abies). In: Biotechnology in Agriculture and Forestry 30: Somatic Embryogenesis and Synthetic Seeds I (YPS Bajaj, ed), Springer-Verlag, Berlin, Germany, 415-430 